\section{Call for Papers: Organizations, Social Inequality, and Social Justice Conference of the Workgroup Sociology of Organizations, the Institute for Employment Research (IAB), Nuremberg, and the Junior Research Group ,Interdisciplinary Social Justice Research" at Humboldt-Universität zu Berlin, April 23-24, 2004.}

During the last decades, social inequality and stratification research has shown that organizations play an important role in creating and sustaining social inequalities in modern societies. Despite these findings a field of investigation which makes systematic use of the theoretical concepts and empirical results from the sociology of organizations has not been established so far within German social inequality and stratification research. One reason may be that allocations of positions and distributions of social goods were for a long time regulated in Germany by institutional arrangements on the societal level.

But there are changes under way: Deregulation and the shifting of decision-making authority to the organizational level are increasingly perceived as a key strategy to overcome the economic crises of the German welfare state. Tariff contracts in various branches of trade and industry now more and more often contain opening clauses allowing rule setting at the firm level, and even organizations within the public education system are receiving more clearance for their own decisions. Hence, we may expect that business firms and organizations of the education system will gain more influence when it comes to the distribution of positions, status and income in the future in Germany.

At the conference, we will discuss the significance of different types of organizations in establishing and reinforcing social inequalities as well as their importance in shaping individual attitudes toward social inequalities and social justice. We welcome contributions from different sociological areas that concentrate on the following issues from a theoretical or an empirical point of view:

(1) Historical and conceptual perspectives on organizations and their contribution to social inequalities and social justice.

(2) Allocation and stratification processes within organizations and their impact on the societal level.

(3) Ecological and bargaining relationships between organizations and the consequences for social inequality.

(4) Organizational structures and attitudes towards social inequality and social justice.
Paper sessions will be introduced by keynote presentations by Glenn Carroll (Stanford University, requested), J. Richard Hackman (Harvard University, requested), Arne L. Kalleberg (University of North Carolina. Chapel Hill) and Charles Perrow (Princeton University, requested). Full papers or extended abstracts (about 2-3 pages) should be sent by January, 15, 2004, to the local organizers Stefan Liebig and Holger Lengfeld, Junior Research Group „Interdisciplinary Social Justice Research", Humboldt-Universität zu Berlin, Institute of Social Sciences, Unter den Linden 6, D-10099 Berlin, email: stefan.liebig@rz.huberlin.de.

\section{„Nationalliteraturen nach 1945: Autonomisierung, Professionalisierung, Internationalisierung“"}

Zu dieser Tagung hatten Ingrid Gilcher-Holtey, (Fakultät für Geschichtswissenschaft, Philosophie und Theologie der Universität Bielefeld) und Gisèle Sapiro (Centre de Sociologie Européenne Paris) vom 22. bis 24. Mai 2003 Soziologen, Historiker, Anthropologen und Literaturwissenschaftler aus Frankreich und Deutschland, Kanada, Argentinien, Italien, Norwegen, den Niederlanden, Schweden, Spanien und Österreich in das Zentrum für interdisziplinäre Forschung in Bielefeld eingeladen.

Orientiert an Fragestellungen, Begriffen und Hypothesen der Feldtheorie Pierre Bourdieus, unternahm die Tagung den Versuch, Entwicklungslinien innerhalb der Felder der Nationalliteraturen nach dem Zweiten Weltkrieg zu erfassen und die Beziehungen zwischen einzelnen nationalen literarischen Feldern zu untersuchen. Von Bourdieus zentraler Annahme ausgehend, dass "Feld“ als „Ort von Kräften - und nicht nur Sinnverhältnissen und von Kämpfen um die Veränderung dieser Verhältnisse" zu verstehen sei, widmete sie sich den Kämpfen um die Definition von Autorschaft und Literatur sowie den Distributions- und Produktionsbedingungen des literarischen Feldes. Die in französischer Sprache geführte Debatte hatte vier Schwerpunkte:

Zu Beginn ging es um die Herausbildung und Struktur sowie die Neu- und Umgestaltung nationaler literarischer Felder. Anhand von Fallstudien zum italienischen (Anna Boschetti), belgischen (Paul Aron), norwegischen (Kjetil Jakobsen), österreichischen (Franziska Schößler und Juliane Vogel) und niederländischen (Kees van Rees) literarischen Feld wurden charakteristische Besonderheiten und übergreifende Gemeinsamkeiten 